\title{
Ballot Paper Wastage in Elections in Ghana: Reflections of Electoral Commission Officers and Voters in the Jaman South District
}

\author{
${ }^{*}$ Daniel Odoom ${ }^{1}$, Ernest Opoku², Edward Gyamfi ${ }^{3}$ \\ ${ }^{1}$ Institute for Development Studies, University of Cape Coast-Ghana \\ 2Institute of Education, University of Cape Coast-Ghana \\ ${ }^{3}$ District Electoral Office, Wenchi District-Ghana \\ *Email: ankahodoom@gmail.com
}

\begin{abstract}
This paper investigated the reflections of Electoral Commission (EC) officers and voters in the Jaman South District with regard to ballot paper wastage in elections in Ghana using descriptive exploratory research design. Purposive and convenience sampling techniques were used to select 172 respondents for the study with questionnaires, structured interview and interview guide as the research instruments. The study revealed that elections were conducted to help select leaders for the nation and to help ensure that leaders are accountable to the people. Policies and ideologies of candidates were found to have little influence on how persons vote. Factors such as protest voting, low public education on elections, and high level of illiteracy were responsible for rejected ballots in the district. Rejected ballot paper was a cost to the EC officers and the voters in terms of resources, time and energy especially during periods of run-offs. The study recommended that the government effectively collaborate with the EC officials in the district to implement policies that will increase voters' appreciation of issues underpinning democracy. The EC officers in the district should properly collaborate with the National Commission for Civic Education (NCCE) to provide adequate public education to enable the electorates in the district to have a proper understanding of basic electoral issues.
\end{abstract}

Key words: Elections; democracy; democratization; disenfranchisement; rejected ballots.

\section{Introduction}

Democracy remains a universally valid system of governance, albeit one which needs to be backed up by constitutionally guaranteed rights (Smith, 2004). The last quarter of the $20^{\text {th }}$ century has witnessed the greatest expansion in democracy in history. Democracy is defined in the minimal sense-as a system of government in which the principal propositions of political power are filled through free, fair and regular elections (Hutchful, 2001). Linz and Alfred (2001) argue that for a democracy to be consolidated, a number of pre-conditions such as free civil society, a relatively autonomous and valued political society, the rule of law to guarantee citizens freedoms, independent judiciary and functioning state bureaucracy must exist. As a structured system to enhance democracy and development, different political systems have evolved over these years ostensibly to attain and maintain social balance (Gibbson, 2008; Smith, 2004). Development literature suggests that genuinely competitive elections are the most significant dimensions of a liberal democracy (Cox, 2000).

Democracy means different things to different people. Afrifa (2005) maintained that it is a method, a process, a system, an ideology, a platform for power contestation and not the least a class struggle. In the view of Aristotle, democracy is a government in which the whole body of citizens share power, but in which they use it for selfish purposes (Cox, 2000). Again, Abraham Lincoln defined it as "government of the people, by the people, for the people" and in the opinion of Bryce, it is a government in which majority will prevail. Democracy is both a form of government and a way of life (Cox, 2000; MacLean, 1998).This produces some divergence between and within democratic theory and democratic politics, making democracy rather ambiguous and highly ideological (Cox, 2000; Boafo-Arthur, 2006b). With this, Buadi (2004) has observed that elections in Africa are at best superficial. He posits that under multi-party democracies in Africa, poverty and illiteracy, 
oppression and disempowerment of the people combine to reduce their political potency. Thus, the pre-eminence of the people as being central in the principal-agent relations implied by representative democracy is seriously compromised (Cox, 2000).

Structural imbalances make it possible for the agent in the political-agent relationship to dominate the political processes and determine the possibilities and probability of outcome due to inequalities and inequities (Gyimah, 2003).To the democratic peace theorists, non-democracies are societies in which violence and coercion prevail. In such societies, highly conflictive relations make internal democracy precarious, especially where there is strong opposition. The result is mistrust and fear within and outside government (MaOz and Russett, 1993). Consequently, a non-democratic state apparently lacks the institutional and behavioral constraints for war. Voting is one of the most efficient tools in any democracy. Openness is usually considered a cornerstone of a democratic system, especially, the act of voters' registration which is usually an important exercise (Hutchful, 2001). It is crucial in most free and fair elections since it provides information on the total number of eligible voters and prepares the voters for the actual voting (Cox, 2000; MacLean, 1998). A number of factors affect how persons vote in democratic regimes. Notable among these factors are personal characteristics of the candidate, the area the candidate comes from, the party of the candidate and the candidate's policies (Moser and Scheiner, 2005; Raunio, 2004).

The Electoral Commission (EC) of Ghana is constitutionally empowered to organize, undertake and supervise all elections; to register political parties and compile voters' list, as well as to disburse subventions to political parties and monitor them. Through the EC and political parties, citizens are thoroughly educated on how to thump print the ballot papers in electing their political officials. Procedures such as registration, balloting and counting; the roles and responsibilities of elected officials, the manner in which results are gathered and analyzed are also spelt out to the citizenry (Electoral Commission of Ghana, 2012). The Ghana electoral system is the single member constituency type with competitive multiparty and the first past the post winner system.

The method of voting used in four out of five past elections that is, in 1979, 1992, 2000 and 2008 was the Open Ballot System (OBS) in which the prospective voter goes through a process of accreditation, receives a ballot paper from the appropriate poll official and there after makes the confidential thumb impression in favor of the political party or candidate of choice in a secret voting compartment before dropping the ballot in the box positioned in the open, in the full glare of officials, security and party agents (Boafo-Arthur, 2006b; EC, 2012).

The modified open ballot system was adopted in the 1993 elections, in which voters filed behind the party symbol or photograph of the candidate of choice (Boafo-Arthur, 2006b). Voters were physically counted at the close of polls and the results declared to officials, security and party agents. Although the method is simple and produced what many in Ghana have often described as the fairest and most peaceful elections in the country, the election had some challenges (Ninsin, 1998). The election involved seven parties, a clear departure from the over thirty political parties of today, and also suffered the flaw of not providing the voter with the secrecy of ballot- a basic internationally acceptable standard for any elections (Boafo-Arthur, 2006b). All the electoral systems used allow disputed results to be challenged by way of election petitions, judiciary hearings and determined at tribunals or courts established for the purpose as the case may be (Ayee, 2001; EC of Ghana, 2012). Even though pre-election violence has been recorded in Ghana, and some of the incidents reported are of a serious nature, they have not degenerated into widespread chaos.

The main contention has been the spoilt ballot papers rejected by EC and the impact this wastage could have on the outcome of the elections. Brown (2008) posits that the large number of rejected ballot could lead to disenfranchisement of a large number of eligible Ghanaian adults in 2008 general elections and concluded that all sorts of strategies need to be made to deal with the phenomenon. The pattern of rejected ballot papers in elections has been remarkable. In the1992 elections 64,354 (3\%) ballot papers ballots were rejected while in 1996, a total of 111,108 (1.53\%) ballot papers were rejected. Rejected ballot papers accounted for 104,214 (1.58\%) and 188,123 (2.13\%) in 2000 and 2004 presidential general elections respectively. The percentage of rejected ballot papers further increased to 205,483 (2.4\%) in 2008 (Yankah, 2009).

Spoilt ballot papers in elections have been of great concern to many people in Ghana. Acheampong (2006) blamed the large number of rejected ballot papers in the 2008 general elections on the lack of planning and effective public education. There has been a call on the EC to intensify education on voting to reduce the high incidence of rejected ballot papers (Gyampo, 2009; Yankah, 2009). However, Smith (2004) opines that educating the electorates was not the issue but inherently the ballot system of voting had outlived its usefulness. Smith (2004) further admits 
that had the $2.4 \%$ rejected papers in the first election been accepted it could have tilted the results thereby saving the nation of cost in resources, time and energy for the run-off. Several incidences of spoilt and rejected ballots continue to engage the attention of many election administrators, policy makers and politicians in Ghana. For instance, the rate of ballot papers declared invalid in the Jaman South district during the 2004 presidential elections was 445 (representing $1.4 \%$ of the total votes), with the 2008 elections recording 724 (representing $2.36 \%$ of the total votes), while the 2012 elections recorded 1022 (representing $2.56 \%$ of the total votes) (Electoral Commission of Ghana, 2012).

The figures show that since the carving out of the district in 2003, there has been a steady increase in the number of rejected ballot papers in the district. Despite the public outcry about the high incidence of rejected ballots, there is no empirical study in the country to situate the issues into its proper perspective. This study therefore sought to fill the gap by examining the reflections of EC Officers and voters on the rejected ballots in the Jaman South district in order to come out with measures for improvement.

Specifically, the study, among other things, sought to ascertain the views of voters and electoral officers in the Jaman South district regarding the factors that affect how persons vote; to examine the factors responsible for ballot paper wastage in the Jaman South district; to ascertain the views of voters and electoral officers on the effects of ballot papers wastage on election outcomes; and to determine the views of electoral officers and voters on the level of education given to the electorates in the Jaman South district.

\section{Methods}

\subsection{The study setting}

The Jaman South district is one of the twenty two (22) administrative districts in Brong-Ahafo Region of Ghana. It shares common borders with Berekum Municipal Area to the south-east, Jaman North District to the north, Dormaa Municipal Area to the south and La Cote d'Ivoire to the west. The district with its capital at Drobo has a total land area of about 700 square kilometres. The district has about 130 settlements most of which are rural. It has a total land area of 1,500 square kilometres (Ghana Districts Report, 2012). The district population according to the 2010 Ghana Statistical Service (GSS) is 92,649 comprising 43,459 males and 49,190 females (GSS, 2012). The district is divided into twenty seven (27) electoral areas and one hundred and eighteen (118) polling stations (Electoral Commission of Ghana, 2012). The major occupation in the district is Agriculture which absorbs 61.7 percent of the total labor force in the district (GSS 2000). The Jaman South Constituency was carved out of the then Jaman Constituency in 2003 by the EC. Since its creation as a constituency, Jaman South has witnessed three different major elections- 2004, 2008 and 2012 with various political parties including the New Patriotic Party (NPP), the National Democratic Congress (NDC), Convention People's Party (CPP) and the People's National Convention (PNC) participating in these elections organized.

\subsection{Research design}

The study design was both qualitative and quantitative. It was exploratory and descriptive. Exploratory research examines the relevant factors in detail to arrive at an appropriate description of the reality of the existing situation. Exploratory research attempts to identify new knowledge, new insights, new meanings and the factors related to the issue (Babbie, 2004; Sarantakos, 2005). Babbie (2004) concedes that the results of exploratory studies provide a better understanding of the sample being examined. Though the work of Yankah (2009) established that ballot paper wastage has been a problem, research is yet to reveal the specific factors that have led to the existing situation in the Jaman South District. The study was also descriptive because it entailed a systematic collection and presentation of data on various issues of ballot paper wastage in the Jaman South district to give a clearer picture of the prevailing situation. Thus an exploratory descriptive research design provides an opportunity to examine all aspects of the problem (Sarantakos, 2005).

\subsection{Population study}

Population is the group to which the results of the study are intended to apply. That is the target group about which the researcher is interested in gaining information and drawing conclusions (Sarantakos, 2005). The target population of the study comprised the officials of the district electoral commission made up of both permanent officers and temporary staff of the Electoral Commission, as well as the voters in the study area. 


\subsection{Sample and sampling procedure}

The study employed purposive, random and convenience sampling techniques to draw respondents for the study. In his views, Babbie (2004) posits that purposive sampling is a type of sampling technique in which the researcher selects the sample on the basis of his own judgments about which population will be the most representative. The underlying assumption behind the use of this technique was that with good judgment and appropriate strategy, the researcher could handpick the cases to be included in the sample and thus develop sample units that are relevant and satisfactory for the study. The EC officials were purposively selected for the study because of their respective roles in elections in the district. These persons constituted the key informants involved in the study. There were two categories of EC officials namely, the permanent officers and the temporary officers. There nine permanent officers involved in the study. These were the District Electoral Officer, the Deputy Electoral Officer, five Electoral Assistants, the Electoral Supervisor as well as the Secretary.

Besides, the temporary EC officers involved in the study were the Returning Officer (RO), two Deputy Returning Officers (DROs) as well as the Presiding Officers. There were 118 Presiding Officers (POs) in the district. According to Krejcie and Morgan (1970), for a population of 118 POs, 92 should be selected at $(5 \%)$ error margin with 95 percent confidence level. However, due to time and financial constraints, $46(50 \%)$ of the required number were selected for the study through random sampling technique. The list of all the POs in the district was obtained from the District Electoral Office. Random sampling was used to select 46 POs. Convenience sampling was used to select voters from the district using the 2012 Electoral Register for the constituency.

Convenience sampling is a non-probability sampling technique where subjects are selected because of their convenient accessibility and proximity to the researcher (Babbie, 2004). There were 50494 registered voters in the district (Electoral Commission of Ghana, 2012). According to Krejcie and Morgan (1970), for a population of 50494 voters, 381 should be selected at (5\%) error margin with 95 percent confidence level for a representative sampling. However, the researchers used $114(30 \%)$ of the statistically required sample size using convenience sampling technique. This was in line with the views expressed by Sarantakos (2005) which show that fewer numbers will enable thorough examination of issues in exploratory research. In all, a total of 172 respondents made up of 58 EC officers (nine permanent officers and 49 temporary officers) and 114 voters were involved in the study.

\subsection{Data collection instruments}

The main instruments used for the collection of the data were questionnaires, interview guide and interview schedules. A set of questionnaires was used to gather data from the Presiding Officers, the Election Assistants, the Election Supervisor, and the Secretary. Demographic items were placed at the end of the questionnaire and the interview schedule since in Dillman's (1998) view, it is not necessary to start a question with demography because it puts respondents off in answering the questions before them. A set of interview schedules was used to collect data from voters within the district while the interview guide was used to solicit data from the District Electoral Officer, the Deputy Electoral Officers, the ROs and their Deputies. The instruments sought to gather relevant data on issues such as the factors that affect how persons vote, factors responsible for ballot papers wastage and the effects of ballot papers wastage on election outcomes.

\subsection{Data collection procedure}

There was a pilot study which preceded the main data collection. The pilot study took place at Jaman North District. This district was chosen because it has similar geographic and socio-economic characteristics as the Jaman South district which is the study area. The pilot survey was done to enable the field assistants understand the research instrument and to make corrections where necessary before the actual data collection commenced. The results of the pre-test informed the level of aptness of the instruments. The results also made it possible for some alterations and redesign of the instruments with view to ensuring accuracy and validity of the data collected. Primary data was collected by the researcher and four field assistants who were recruited and given the necessary training to enhance the data collection exercise.

\subsection{Data processing and analysis}

The data were further re-organized in a form that could suit quantitative and qualitative analyses. Qualitative analysis took the form of transcribing recorded tapes, content and documentary analyses, whilst quantitative analysis took the form of descriptive statistics such as frequencies and percentages with the aid of the Statistical Product and Service Solution (SPSS) version 16.0. Data generated 
from questionnaires and the closed ended questions in interview schedules can be analyzed using descriptive statistics such as frequencies and percentages that enable the researcher to draw inferences, deductions and relevant conclusions. Appropriate content analysis can also be made of the open-ended questions from the interview schedules (Corbetta, 2003; Grosshans, 1991). Babbie (2004) and Sarantakos (2005) argue that with data collected by the use of questionnaires and interview guides and schedules, researchers ought to be guided by an analytical procedure which suits both qualitative and quantitative studies. Sarantakos adds that in qualitative analysis, personal choices, preferences and decisions as well as subjective views about truths and knowledge form the basis for inquiry. Qualitative analyses, documentary analysis and descriptive statistics were employed for data collected for the study.

\section{Results and Discussion}

The background characteristics of the respondents studied were sex, age and educational levels. These characteristics were studied to serve as bases for differentiation with regard to the views of electoral officers and the voters on ballot papers wastage in the Jaman South district. Out of the 172 respondents, 62.8 percent of them were males while 37.2 percent were females as shown in Table 1.This implies that there were more males involved in the study than females.

Table 1

Sex and age of respondents

\begin{tabular}{lll}
\hline Sex/Age & Frequency & Percentage \\
\hline Male & 108 & 62.80 \\
Female & 64 & 37.2 \\
\cline { 1 - 1 } $\begin{array}{l}\text { Age of } \\
\text { respondents }\end{array}$ & & \\
\cline { 1 - 1 } Less than 20 years & 12 & 6.98 \\
20-30 years & 43 & 25.00 \\
31-40 years & 51 & 29.65 \\
40-50 years & 26 & 15.12 \\
51-60 years & 29 & 16.86 \\
Above 60 years & 11 & 6.39 \\
\hline
\end{tabular}

Source: Field survey, 2013

On the relevance of gender in democracy, McDermott (1998), in his study, demonstrated that voters used candidates' gender and race as a cue to policy positions. McDermott adds that the physical attractiveness of a political candidate may be used as an information shortcut by voters, who infer that beautiful candidates have other positive traits. The age distribution of the respondents was informed by section 28 (5) of the 1992 Constitution of Ghana which classifies adulthood from age 18. From Table 1, the majority (54.65\%) were between 20 and 40 while
23.25 percent were above 50. This implies that there were more respondents within the ages of $20-40$ who were involved in the study. Clearly, this picture is symptomatic of the age structure of the country's population where the population rate of the youth is found to dominate. Owing to the onerous and sensitive responsibilities entrusted to the EC officers, personnel of the EC require high educational qualifications in addition to their experience in order to ensure smooth democratization. The educational qualifications of the respondents are presented in Table 2.From Table 2, it can be said that the majority $(52.9 \%)$ had educational qualification not more than SHS while 25 percent had first degree as their qualification. It was also observed that 17 of the Presiding Officers had qualifications below Higher National Diploma (HND).Sensitive positions such as Presiding Office may require qualifications that are even higher than Diploma. In his view, Safty (2004) contends that an educated population is an essential ingredient to the fostering of a democratic society. Safty bemoans that in nations where the leaders fail to institute measures to educate the citizenry democracy finds it very difficult to thrive. Analoui (2007) believes quality education is the bastion of human resource development and the growth and survival of nations.

Table 2

Educational level of respondents

\begin{tabular}{lll}
\hline Education level & Frequency & Percentage \\
\hline Below SHS & 62 & 36.04 \\
Up to SHS & 29 & 16.86 \\
A Level & 11 & 6.39 \\
HND/Diploma & 21 & 12.21 \\
First Degree & 43 & 25.00 \\
Masters & 6 & 3.48 \\
\hline Total & 172 & 100 \\
\hline Source: Field survey, 2013 &
\end{tabular}

Elections are essential part of democracy. They serve as means of electing leaders for national and local levels as well as providing peaceful transition of government. On the issue of whether the registered voters and the EC officials had ever voted in any national elections before, the study found that 89.4 percent of the registered voters stated that they had voted before while 10.6 had a contrary view. Almost all the EC officials had voted in national elections before. In the words of a key informant, "Elections are very key in democracy so there is the need for all of us to actively take part in it". The number of times the respondents had taken part in national elections differed. For instance, about 64 percent of the 
registered voters had voted 3-4 times, 23.3 percent had 5-6 times 12.7 had voted 1-2 times. The results from the questionnaire also revealed that 66 percent of the officials had voted 3-4 times while about 32.7 percent had voted 5-6 times. Generally, it can be said that the respondents had some level of experience as far as their participation in elections is concerned.

With regard to the views of the respondents on the criticality of elections to national development, varying responses were obtained from the voters. For instance, 43.86 percent of the voters believed that elections are conducted to help select leaders for the nation, 18.43 percent indicated it was to help reduce oppressive rule while 18.43 percent believed they are organized to ensure that leaders are accountable to the people. In the words of a respondent, "Elections are important for a number of reasons such as to help ensure that leaders are accountable to the people; to help get rid of autocratic government; and to create an environment for the citizens to participate in governance." Other respondents stated that through elections a country is able to get leaders to govern its people.

In most democracies, prime ministers and presidents are elected by national elections. Not only presidents are elected through elections but also members of parliament. The members of parliaments undertake to represent the interest of the people in decision making. They make laws to govern the country. Elections reduce oppressive rule. This is in line with the Article 21 of the Universal Declaration of Human Rights (1948) which states that periodic and genuine elections are seen as a key component of enhancing legitimacy of a government and strengthening the social contract between citizens and their governments.

Furthermore, elections allow for peaceful transition of government. In democracy governments can be voted in and voted out. When the support of the people for a particular government diminishes the government is likely to be voted out. This promotes peaceful transition of government. The findings above support that of Awa (1991) who argued that elections in democracy help reduce oppressive rule, help ensure peaceful transition of government and also help ensure that citizens actively participate in the governance process. Beyond this, Awa observes that surprisingly, there is a trend towards declining public interest in elections, increasing citizens' disengagement from public affairs and distrust of government which appear to be the result of failure of leaders. According to the International Peace Institute (IPI) (2012), successful transfers of power in countries such as Niger and Guinea following authoritarian rule and military coups have resulted in significant process towards peace and stability in the region.

A number of factors are responsible for the way and manner persons decide to vote in democratic systems of government. From Table 3, it is clear that the majority $(85.1 \%)$ of the respondents generally believed that the characteristics of candidates affect how they voted for them while 14.4 percent had a contrary view.

Table 3

Factors that affect how voters in the Jaman South District voted

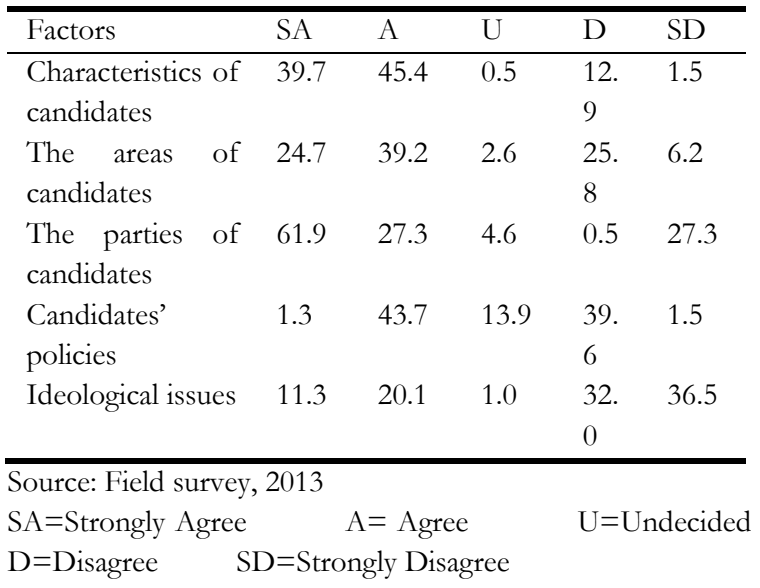

Interview with the EC officials also revealed that the characteristics of candidates influence how persons voted for them. Some of the EC officials generally commented that the characteristics of candidates influence how persons vote in democracy. For instance, in the words of a key informant, "Sometimes the physical features of the contesting candidates attract votes from people". Another key informant intimated that attractiveness of the candidates plays a huge role in how persons vote. In a study conducted by Raunio (2004), it was observed that personal characteristics of candidates appear to weigh more heavily in the minds of Finnish voters.

Again, from Table 3, it is clear that the majority $(63.9 \%)$ of the respondents generally believed that the areas of candidates affect how persons vote for them but 32 percent opposed it. The EC officials generally indicated that the areas of candidates influence how persons vote for them. For instance, the key informants generally stated that the areas of candidates affect how persons vote in democracy. Other officers generally believed that the areas of candidates affect how persons vote. The findings of the study corroborate Marsh (2000) and Swindle (2002) who argue that the area of candidates affects how persons vote for them. 
Furthermore, on the issue of parties of candidates, it was observed from Table 3 that while majority $(61.9 \%)$ of the respondents strongly agreed that they influence how persons vote, 27.3 percent strongly disagreed. Interview with the EC officials also established that the parties of candidates influence how persons vote for them. One key informant believed, "Because political parties are mainly formed on tribal lines sometimes people become so much attached to them. They decide to vote for parties in order to promote the tribal dominance". Additionally, in the words of a key informant, "Sometimes the party you belong to attracts vote from people". Generally, the key informants believed parties of candidates play a vital role in how persons vote which departs from the position of Raunio (2004) that parties of candidates have little role to play on how persons vote.

More so, on the issue of candidates' policies, the study found that about 55 percent of the respondents generally could not state that the policies of candidates affect how persons vote for them as presented in Table 3. Interview with some of the EC officials also revealed that the policies of candidates do not have much influence on how persons vote. Besides, the key informants generally commented that because of literacy most persons do not place much value on policies of candidates when voting. In the words of a key informant, "Policies of candidates have little influence on how persons vote". This study confirms the position of Marsh (2000) that policies of candidates do not heavily affect how persons vote especially in a society where issues of ethnicity and illiteracy are high. On the issue of party ideologies, it is clear from Table 3 that the majority $(68.5 \%)$ of the respondents generally disagreed that the political ideologies of candidates affect how persons vote for them but 31.4 percent agreed. During the interview, the EC officials generally believed that the ideologies of candidates do not affect how persons vote. One key informant bemoaned, "Because of tribalism most voters do not consider the ideologies of candidates before voting".

The findings of the study corroborate Marsh (2000) and Swindle (2002) who opined that the political ideologies of candidates do not have a considerable influence on how persons vote. Moreover, on the issue of factors responsible for ballots papers wastage, it is clear from Table 6that the majority $(85.1 \%)$ of the voters generally believed that protest voting can lead to ballot papers wastage while 13.9 percent had an opposing view. Also, from Table 5 , it can be seen that the majority $(86.1 \%)$ of the respondents generally stated that protest voting can lead to ballot paper wastage while 13 percent had a contrary view. Also during the interview, it was revealed by the Returning Officers and the Deputy Electoral Officers protest voting had the tendency to cause ballot papers wastage. Also, in the words of a key informant, "There are times voters demonstrate their utter disapproval of some candidates by thumpprinting their faces. This invalidates it the vote cast".

Rejected ballots in any election may be result of protest voting. Protest voting occur when vote leave ballot papers blank or internationally thumbprint more than expected. In any election voters are to thumbprint once but when they fail to thumbprint or thumbprint more than expected it could be show of protest against political party or candidates either because of unfulfilled promise or for genuine reasons. The findings of the study support that of Yankah (2009) who contends that as a way of demonstrating their dislike for some candidates, voters decide to engage in protest voting. Regarding the issue of low voter education on elections, it was found that the majority $(69.9 \%)$ of the voters generally indicated that low voter education is a cause of ballot papers wastage while about 27 percent generally disagreed as shown in Table 4. Similarly, from Table 5 , it is clear that about 80 percent of the respondents generally believed that low voter education is responsible for ballot papers wastage. These views were generally supported by the key informants. In the words of a key informant, "We do not provide enough education to the voters and this is not the best because many people still do not understand electoral issues in the country". 
Table 4

Views of the voters on factors responsible for ballot paper wastage

\begin{tabular}{|c|c|c|c|c|c|}
\hline Factor & SA & $\mathrm{A}$ & $\mathrm{U}$ & $\mathrm{D}$ & $\mathrm{SD}$ \\
\hline Protest voting leads to ballot papers wastage. & 40.7 & 44.4 & 0.5 & 12.9 & 9.1 \\
\hline Low voter education on election causes ballot papers wastage. & 39.2 & 30.7 & 1.6 & 20.8 & 6.2 \\
\hline $\begin{array}{l}\text { It is the civic duty of the electorates to ensure that their ballot papers are not } \\
\text { rejected. }\end{array}$ & 26.7 & 23.0 & 21.4 & 22.8 & 6.10 \\
\hline $\begin{array}{l}\text { Distance between where voters dip their fingers in the indelible ink and the } \\
\text { screen where they cast their vote }\end{array}$ & 43.0 & 17.9 & 1.3 & 33.6 & 1.5 \\
\hline Illiteracy can lead to ballot papers wastage & 62.9 & 26.3 & 4.6 & 0.5 & 27.3 \\
\hline
\end{tabular}

Table 5

Views of Presiding Officers, Election Assistants, Election Supervisor and the Secretary on factors responsible for ballot paper wastage

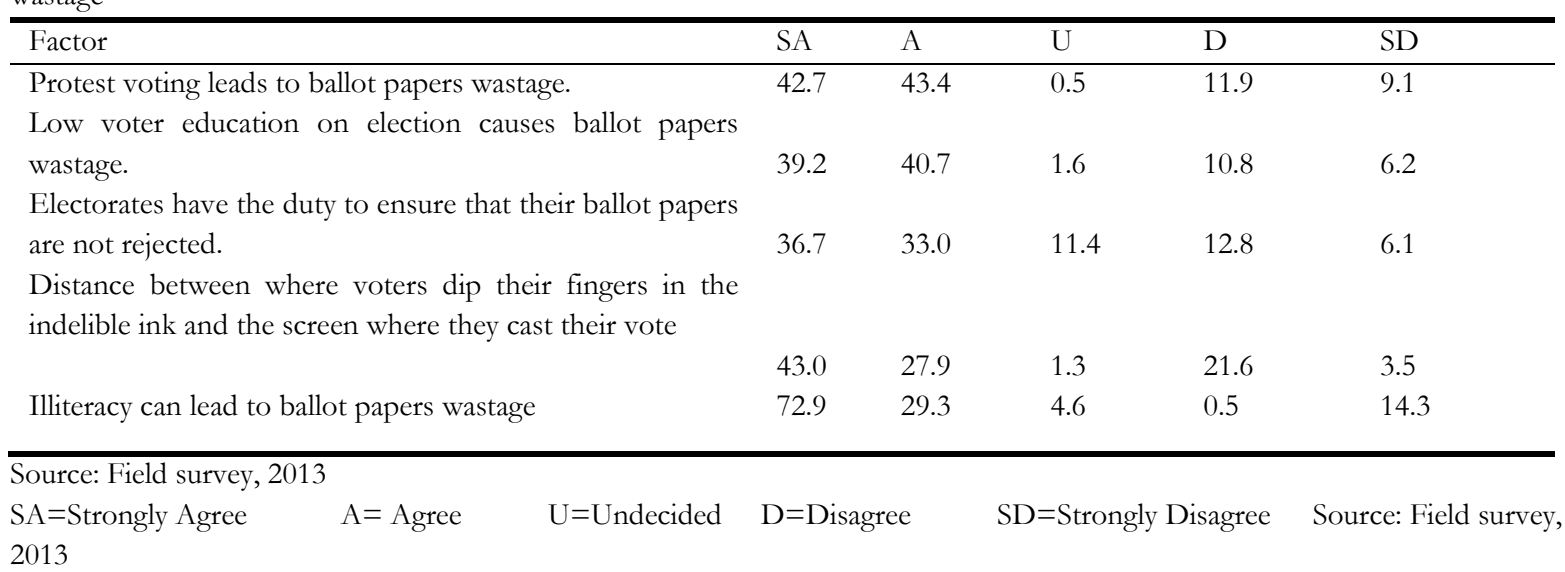

Again, from Table 4, it can be seen that the 49.7 percent of the voters generally believed that it is the civic duty of the voters to ensure their ballots are not rejected while about 29 percent had an opposing view. Also, from Table 5, it is obvious that the majority $(69.7 \%)$ of the respondents generally stated that it is the civic duty of the voters to ensure their ballots are not rejected while about 19 percent had a contrary view. Though during the interview, it was revealed by the some of the key informants that it is the civic duty of the voters to ensure their ballots are not rejected they admitted that this can only be possible when we have an illiterate population. In the words of a key informant, "Most people are illiterate and so may find it difficult to avert their minds to issues of voting". Additionally, the distance between where voters dip their fingers in the indelible ink and the screen where they cast their vote accounts for rejected ballot paper was found to cause ballot papers wastage as shown in Tables 4 and 5. From Table 4, it is clear that the majority $(60.9 \%)$ of the voters generally indicated that the distance between where voters dip their fingers in the indelible ink and the screen where they cast their vote accounts for rejected ballot paper while about 35 percent generally disagreed. In support, from Table 5, it is clear that about 71 percent of the respondents generally believed that the distance between where voters dip their fingers in the indelible ink and the screen where they cast their vote accounts for rejected ballot paper. The views expressed above were generally supported by the some of the key informants involved in the study. One key informant indicated, "Sometimes the distance appears to be too close for one to clearly make a choice".

Concerning illiteracy, it can be seen from Table 6 that the majority $(62.9 \%)$ of the voters strongly agreed that illiteracy is a cause of ballot papers wastage while about 27 percent strongly disagreed. Similarly, from Table 5 , it is clear that about 73 percent of the respondents strongly believed that illiteracy is responsible for ballot paper wastage while 14.3 strongly disagreed. According to the key informants illiteracy is one of the main causes of ballot papers wastage in the district. In their studies, Gyampo (2009) and Yankah (2009) found a positive relationship between illiteracy and incidence of rejected ballot 
paper in Ghana. In order to reduce ballot paper wastage in elections in Ghana, there is the need to improve upon the voting process. Indeed, such improvement ought to begin from the kind of education given to the electorates on elections in general, and voting in particular.

Regarding the issue of whether or not rejected ballot paper posed a problem to the country's democracy, $(69.6 \%)$ of the voters stated that it would, but $(30.4 \%)$ believed it did not. The views of the majority $(69.6 \%)$ of the voters were supported by 89.8 percent of the EC officials during the interview schedule. On their part, the District Electoral Officer, the Deputy Electoral Officers and the Returning Officers generally commented that rejected ballot papers posed a huge challenge to the nation's democracy. Table 6depicts the views of voters on whether or not rejected ballots can affect the outcome of presidential elections.

Table 6

Views of voters on the likelihood of rejected ballot papers affecting the outcome of presidential elections

\begin{tabular}{lll}
\hline Response & Frequency & Percent \\
\hline Very Likely & 71 & 62.29 \\
Likely & 21 & 18.43 \\
Neutral & 3 & 2.63 \\
Unlikely & 13 & 11.40 \\
Very Unlikely & 6 & 5.55 \\
\hline Total & 114 & 100.0 \\
\hline
\end{tabular}

Source: Field survey, 2013

It can also be seen from Table 6 that while the majority $(62.29 \%)$ of the voters believed that rejected ballots will very likely affect the outcome of presidential elections, only 5.55 percent stated that it will very unlikely affect the results. Again, through the questionnaire it was found that while 75.6 percent of the respondents indicated that rejected ballot papers could very likely affect the outcome of presidential elections 19.6 percent had an opposing view. The views expressed above were further proclaimed by some of the key informants who generally intimated that rejected ballot papers will very likely affect the presidential elections. In the words of a key informant, "In some cases, there has been some run-offs for the presidential elections mainly because of the rate of rejected ballot papers". Another EC official also commented that during run-offs as a result of rejected ballots lead to a situation, other candidates decide to team up with other parties which influence the election outcomes.

All these points attest to the fact that the rate of invalid votes encountered by the EC is unacceptable. The effect of rejected ballots on the presidential elections finds relevance given the fact that for instance, the rate of ballot papers declared invalid in the Jaman South district during the 2004 presidential elections was $(1.4 \%)$ of the total votes which was more than the total votes obtained by some of the candidates.

Also, in the 2008 elections the constituency $(2.36 \%)$ of the total votes, while the 2012 elections recorded $(2.56 \%)$ of the total votes) (EC of Ghana, 2008, 2012). It is clear from these figures that since the establishment of the constituency in 2003, there has been a steady increase in the number of rejected ballot papers in the district. Apart from 2004 elections, all the other elections recorded rejected ballots in the district which were higher than the national average (EC of Ghana, 2004, 2008, 2012). In the event that other districts record similar results, then this figure on the national level could have the potential for a run-off for the presidential elections which has implications for the socio-economic conditions of the country. The results corroborate the views expressed by Gyampo (2009) and Yankah (2009) who agree that the outcome of presidential elections is likely to be affected by high incidence of rejected ballots.

The past two elections held in the country have been very close with the 2008 almost close to call. The difference between the votes of the winner and the close contender was 40,000. With regard to parliamentary elections, the study showed that while 50 percent of the voters believed that rejected ballot papers can very likely affect parliamentary elections, 4.38 percent disagreed as shown in Table 7.

Table 7

Views of voters on the likelihood of rejected ballot papers affecting the outcome of parliamentary elections

\begin{tabular}{lll}
\hline Response & Frequency & Percent \\
\hline Very Likely & 57 & 50.0 \\
Likely & 21 & 18.43 \\
Neutral & 8 & 7.02 \\
Unlikely & 23 & 20.17 \\
Very Unlikely & 5 & 4.38 \\
\hline Total & 114 & 100.0 \\
\hline
\end{tabular}

Source: Field survey, 2013

Also, through the questionnaire it was established that 47.9 percent of the respondents believed it can affect parliamentary elections, 38. 3 percent believed it cannot while 13.8 decided to remain neutral. The Returning Officers admitted that the situation is not that serious than in the case of the presidential elections. In effect, it is clear that rejected ballots can sway the parliamentary results. The District Electoral Officer stated that for instance, in the 2004 general elections the NPP and the NDC which are the dominant political parties in the constituency obtained 17842 and 12085 respectively. With rejected ballots of 247 , had the elections results been so close the number of rejected papers would have given a different winner for the elections. The situation in the 2008 elections is 
even more revealing given the results obtained by the two dominant parties.

The NPP and the NDC obtaining 16878 and 10372 respectively, while the independent candidate had 2654. The rejected ballots stood at 540 which was more than the votes obtained by the remaining individual candidates (EC of Ghana, 2008). Another EC officer said, "If the results between the two dominant parties are so close then the issue of rejected ballots will be critical". The Officer added that in such cases the nation will have to spend money for a run-off election which could have been avoided if people had voted well. What was even frightening, according to the Officer, is that such increased rejected ballots in a party's strong hold can lead to violence. Also, in the 2012 general elections the results for the various political parties showed apart from the NDC (with a total valid votes of 16123), the NPP (with a total valid votes of 22835) and the PPP (with a total valid votes of 403), the rest of the candidates had total valid votes lower than the total rejected ballots (EC of Ghana, 2012).

Though the EC officials generally believed that the total rejected ballots from the elections could influence the outcome of the elections, they admitted that because the parliamentary elections in the country which does not necessarily require candidates to have 50 percent plus one vote to be declared as winners, this effect may not be seriously felt as it pertains in the case of the presidential elections. The EC officials however strongly indicated that rejected ballot papers have serious implications on the budgetary allocations of the EC. They generally believed that instances where there are run-offs due partly to large number of rejected ballot papers, the Commission has to pump more funds into organizing the run-offs. But sometimes the Commission may find it difficult to quickly receive funds from the central government to undertake the elections. Officials who are involved in the run-offs both permanent and temporary officers must all be paid or given allowance which sometimes brings a huge financial burden to the Commission. In the words of a key informant, "There are times the Commission delays in paying personnel involved in organizing the run-off elections since the central government may not have properly envisaged the possibility of a run-off.

Electoral experts have argued that rejected ballots can impact electoral outcomes. According to Gyampo (2009), in the 2008 elections, had the rejected ballots been valid one of the leading contestants (Nana Addo Dankwa Akufo-Addo of the NPP and Prof. John Evans Atta Mills of the NDC) might have won the first round elections. Yankah (2009) also espouses this view by arguing that if planners of the 2008 elections had done their homework well, the district called Tain, would probably have had no business deciding who won the Presidential election. The second round (or even the third) elections appeared to be unnecessary had proper measures been put in place to reduce the rate of rejected ballot papers (Yankah, 2009). On the issue of voter education in the District, it was observed that 65.8 percent of the voters stated that they were poorly educated, while 34.2 indicated they were well educated. However, the results from the questionnaire showed that 56.6 percent stated that they were poorly educated, while 43.4 indicated they were well educated. This means that the level of voter education in the Jaman South district was poor. On their part, the EC officers conceded that voter education in the district was a problem. For instance, the results from the questionnaire also showed that while 56.8 percent of the EC officers stated that they were satisfied with the level of voter education in the district, 43.2 percent disagreed. They cited inadequate funds and poor logistics as the reason for the existing situation.

They were however quick to add that the situation only reflects what happens across the country. With regard to the means by which EC officers educate them on elections, the voters cited community durbars (18.43\%); visit to churches, mosques and organized association (43.86\%); print and electronic media (18.43\%), among others as some of the means. Similar means were identified by the EC officials. Though the key informants stated that the political parties have a role to play in educating the electorates, they admitted it is the duty of the National Commission for Civic Education (NCCE) to educate the public on all aspects of civic duties including elections. Yankah (2009) argues that high rate of rejected ballots is an evidence of low public education on elections. In the words of a key informant, "When we give more people access to quality education they easily understand issues of election." The Officer added that in every election there are first time voters and that these people have to be educated on how to vote and the essence of voting must be made clear to them so that they attach importance to the whole election process. Electronic voting is a sure way of reducing rejected ballot paper wastage in national elections since there are no ballot papers involved, though its implementation may pose a problem due to illiteracy and the cost of using electronic voting devices. 


\section{Conclusions}

Elections serve as means of selecting leaders for national and local level development as well as providing peaceful transition of government. It was established that elections were conducted to help select leaders for the nation, help reduce oppressive rule, and to ensure that leaders are accountable to the people. Factors that affect how persons vote included the characteristics of candidates, the areas of candidates, and parties of candidates. Policies and ideologies of candidates were found to have little influence on how persons vote for them. Factors that account for rejected ballots are low public education on how to cast a valid vote, high level of illiteracy among electorates and protest voting. Rejected ballots could have implications in terms of financial resources, time and energy especially in the instances of run-offs. High incidence of rejected ballots could be reduced by intensification of public education, adoption electronic voting and reduction in illiteracy level. The study recommended that the government should effectively collaborate with the EC officials in the district to implement policies that will increase voters' appreciation of elections in democracy. The government should effectively collaborate with the District Assembly to devise measures including free education, scholarships and/or bursaries to the deprived districts aimed at reducing the rate of literacy. The EC, the NCCE, the political parties as well as civil society organizations should properly collaborate with the NCCE to provide adequate public education for the electorates in the district. The EC should adopt efficient methods of conducting elections such as adoption of electronic device in Ghana in order to prevent rejected ballots.

\section{Acknowledgments}

Our appreciation goes to all the Electoral Commission officers at the Jaman South District for their patience in providing us with the relevant data and documents for this research paper. We are also grateful to all the voters in the Jaman South District who provided us with the needed information and spent time to answer questions which contributed to the success of this research paper. We are particularly grateful to Mr. Christian Kyeremeh, a Lecturer at the School of Business, Sunyani Polytechnic for proofreading this research work for us.

\section{References}

Acheampong, J. K. (2006). The power of incumbency. Canadian Journal of Political Science, 21, 323-33.

Analoui, F. (2007). Strategic human resource management. London: Thomson Learning.
Babbie, E. (2004). The practice of social science research $\left(12^{\text {th }}\right.$ ed.). Wadsworth: Cengage Learning Inc.

Brown, A. S. (2008). Electoral reforms and sustainable development. Accra: CDD-Ghana.

Carty, R. K. (1981). Party and parish pump: Electoral politics in Ireland. Waterloo, Ontario: Wilfrid Laurier University Press.

Cox, G. W. (2000). Electoral coordination In R. Rose (ed.). International Encyclopedia of Election. London: MacMillan.

Dahl, R. A. (2005). What political institutions does large democracy require? Political Science Quarterly, 120, 187-197.

Dillman, D. A. (1998). Mail and other self-surveys in the $21^{\text {st }}$ century: The beginning of a new era. Retrieved from http//survey.Sesrc.wsu.edu/dillman/papers.htm

Electoral Commission of Ghana (2012). 2012 Presidential elections results. Retrieved from,http://www.ec.gov.gh/assets/Copy $\% 20 \mathrm{tb} / \mathrm{s}$ ummaries(1).xls

Electoral Commission of Ghana (2012). 2012 registered voters per constituency. Retrieved from,http://www.ec.gov.gh/assets/Copy $\% 20 \mathrm{tb} / \mathrm{s}$ ummaries(1).xls

George, S. (2005). Democratic development: Designing institutions for citizen participation. New York: Cambridge University Press.

Hutchful, E. (2001). Security, law and order. Dakar: CODESRIA. XXVI, (1\&2), 8

Gyampo, R. E. V. (2009). Rejected ballots and democratic consolidation in Ghana's fourth republic. African Research Review, 3(3), 282-296.

Hutchful, E. (2001). Security, law and order. Dakar: CODESRIA. XXVI, (1\&2), 8

Jonah, K. (2003). The social significance of Ghana's 2002 district level elections in the Upper East Region. Accra: Institute for Economic Affairs.

Krejcie, R. V., and Morgan, D. W. (1970). Determining sample size for research activities. Educational and Psychological Measurement, 30 (3), 607-610.

Linz, J. J., and Alfred, S. (1996). Problems of democratic transition and consolidation: Southern Europe, South America, and Post-Communist Europe. Maryland: The John Hopkins University Press.

Marsh, M. (2000). Candidate centered but party wrapped: Campaigning in Ireland under STV, in Shaun, B. and Bernard, G. (eds). Elections in Australia, Ireland and Malta under the Single Transferable Vote, pp. 114-30. Michigan: Michigan University Press

Ninsin, K. A. (1998). Postscript: Elections, democracy and elite consensus. In K.A. Ninsin (ed). Ghana: Transition to democracy. Dakar: CODESRIA.

Ocquaye. M. (1999). Towards democratic consolidation in Ghana: A study of the Judiciary and its relationship with the executive. Six years of constitutional rule in Ghana. Accra: Freidrich Ebert Foundation. 
Ocquaye, M. (2004). Politics in Ghana: Rawlings, revolution and populist democracy. Accra: Tonardo Publications

Raunio, T. (2004). 2004 European Parliament Election Briefing No 16: The European parliament election in Finland, Retrieved from:http://www.sussex.ac.uk/sei/documents/ep ernep2004finland.pdf

Safty, K. J. (2004). Development and democracy. New York: World Bank.Smith, G. (2009). Democratic innovation: Designing institutions for citizen participation. New York: Cambridge University Press.

Swindle, S. M. (2002). The supply and demand of the personal vote. Party Politics, 8, 279-300.

Yankah, K. (2009). Rejected ballots: A stain on Ghana's democracy. Retrieved from http://www.ghanaweb.com/GhanaHomePage/fe autes/artikel.php?ID. 